\author{
KATARZYNA KoWALSKA \\ Uniwersytet Pedagogiczny w Krakowie, Polska \\ Pedagogical University of Krakow, Poland
}

\title{
Źródła sukcesu firmy ASTOR na polskim rynku
}

\section{Sources of success of ASTOR company on the Polish market}

Streszczenie: Artykuł składa się z wstępu, zakończenia i dwóch rozdziałów o charakterze teoretyczno-analitycznym. W pierwszym punkcie przedstawiono najważniejsze założenia nowego paradygmatu w biznesie - tzw. czterolistnej koniczyny. Wskazano w nim również na znaczenie kompetencji, ich rozwoju w procesie osiągania przewagi konkurencyjnej na zmieniającym się rynku. Drugi punkt artykułu stanowi studium przykładu. Na przykładzie polskiej firmy ASTOR, zaprezentowano praktyczne zastosowanie formuły czterolistnej koniczyny. Omówiono w nim sposób rozumienia i prowadzenia biznesu przez zarządzających organizacją. W artykule wykorzystano metodę opisową z wykorzystaniem analizy literaturowej i danych zastanych oraz połączenie metody sondażu diagnostycznego i metody analizy obserwacji indywidualnych przypadków przy wykorzystaniu kwestionariusza wywiadu pogłębionego. Celem niniejszego artykułu jest identyfikacja źródeł sukcesu firmy ASTOR na polskim rynku. Tak określony cel pozwolił na sformułowanie hipotezy: Kluczowym czynnikiem sukcesu, zapewniającym sprawność operacyjną, wyróżnialność marki i unikalność kultury organizacyjnej, jest profesjonalne podejście do przedmiotu działalności w oparciu o wartości humanistyczne.

\begin{abstract}
The article consists of an introduction, a conclusion and two chapters of theoretical and empirical character. The first section presents the most important assumptions of the new paradigm in business - the so-called four-leaf clover. It also points out on the importance of competencies and their development in the process of gaining competitive advantage on the changing market. The second part of the article is a case study. Using the example of the Polish company ASTOR, the practical application of the four-leaf clover formula was presented. It discusses how the organisation's managers understand and conduct business. The paper uses a descriptive method with the use of literature analysis and desk research of existing data, as well as a combination of the diagnostic survey method and the method of analysis of individual case observation with the use of an in-depth interview questionnaire. The aim of this article is to identify the sources of ASTOR's success on the Polish market. It allowed for a formulation of a hypothesis: The key success factor that ensures operational efficiency, brand differentiation and unique organisational culture is a professional approach to business based on humanistic values.
\end{abstract}

Słowa kluczowe: odpowiedzialność; przedsiębiorstwo; wartości; współpraca Keywords: cooperation; enterprise; responsibility; values

Otrzymano: 13 lipca 2021

Received: 13 July 2021

Zaakceptowano: 24 września 2021

Accepted: 24 September 2021 
Sugerowana cytacja / Suggested citation:

Kowalska, K. (2021). Źródła sukcesu firmy ASTOR na polskim rynku. Prace Komisji Geografii Przemysłu Polskiego Towarzystwa Geograficznego, 35(4), 83-96. doi: https://doi.org/10.24917/20801653.354.5

\section{WSTĘP}

Silna konkurencja na rynku, nadmiar informacji i trudność przechwycenia i utrzymania w tych warunkach uwagi klienta, uzasadnia pytanie o realne źródła przewagi konkurencyjnej współczesnego przedsiębiorstwa. Odnosząc się do tego pytania, Robert Kozielski, ceniony specjalista z zakresu marketingu, podkreśla znaczenie kompetencji przedsiębiorstwa i zmian rynkowych jako realnych szans osiągania przez firmy sukcesu na rynku.

Wspomniane zmiany rynkowe dokonują się w wyniku różnych procesów i zjawisk. Wynikają również z trendów i rozwiązań o charakterze politycznym, gospodarczym i społecznym, będących nierzadko od powiedzią na występujące problemy w gospodarce.

Zmiany rynku stwarzają okazje do poszukiwania innowacji, przyczyniają się dorozwoju firm. Umiejętność odczytu tych okazji i trafnej odpowiedzi na nie, a nawet wyprzedzania pewnych zmian na rynku, zależy od kompetencji firm.

Kompetencje te powinny bazować na interdyscyplinarności, profesjonalizmie, autentyczności i zdolności empatii rynku (Kozielski, 2017). Tak budowane kompetencje stanowią skuteczną bazę dla rozwoju firmy, rozumianego jako osiąganie zysków w długim okresie poprzez rozwiązywanie problemów klientów lepiej niż robią to konkurenci (Kozielski, 2017).

Celem niniejszego artykułu jest identyfikacja źródeł sukcesu firmy ASTOR na polskim rynku. Tak określony cel pozwolił na sformułowanie hipotezy: kluczowym czynnikiem sukcesu, zapewniającym sprawność operacyjną, wyróżnialność marki i unikalność kultury organizacyjnej jest profesjonalne podejście do przedmiotu działalności w oparciu o wartości humanistyczne.

W artykule wykorzystano metodę opisową z wykorzystaniem analizy literatury i danych zastanych oraz połączenie metody sondażu diagnostycznego i metody analizy obserwacji indywidualnych przypadków przy wykorzystaniu kwestionariusza wywiadu pogłębionego.

\section{NOWY PARADYGMAT PODEJŚCIA DO BIZNESU}

Szereg zmian i problemów globalnych, głównie o znaczeniu ekologicznym, wymusza konieczność szerszego spojrzenia na procesy społeczno-gospodarcze, odejścia od wąsko rozumianych modeli funkcjonowania podmiotów rynkowych. Powoduje to zmianę polityki Unii Europejskiej i wielu państw - odejście od linearnego modelu gospodarki rynkowej i stworzenia rynku dla nowej, niskoemisyjnej, bardziej konkurencyjnej gospodarki cyrkularnej.

Nowe uwarunkowania biznesowe wynikające ze zmiany optyki i prawideł działania poszczególnych państw, ich gospodarek, wywołują szereg ściśle ukierunkowanych interakcji międzysektorowych (np. sektora publicznego i prywatnego), które mają również przełożenie na relacje wewnątrzsektorowe (np. B2B) i wielosektorowe.

Dla przykładu, sektor publiczny, jako ośrodek kreacji polityk publicznych, zamawiając dobra lub usługi na rynkach, wpływa na wybór biznesowych modeli rozwoju, 
w tym na standardy umów współpracujących ze sobą przedsiębiorstw. Te interakcje pozostawiają również ślad w obszarze zachowań konsumenckich i wzmocnienia ich pozycji relacyjnej na rynku.

Głównym motorem zmian rynkowych są również (lub przede wszystkim) technologie, których zastosowanie oznacza złożoność procesów, dynamiczną turbulentność otoczenia. W literaturze przedmiotu określa się, że warunki biznesu charakteryzują dziś cztery główne cechy: nieprzewidywalność, niestabilność (mobilność), nieograniczoność (dostępność), niezależność (wolność wyboru) (Kozielski, 2017).

Wszystkie te cechy w dużej mierze wynikają ze zmian technologicznych wywołujących konsekwencje w różnych obszarach funkcjonowania rynku. Kształtują realia biznesowe, w których niepewność jutra, słabsze (w pewnym sensie) powiązanie firm i klientów z danym rynkiem i rosnący wpływ i dominacja klienta (dostęp do różnych kanałów sprzedaży, informacji pozwalającej optymalizować zakup i weryfikację autentyczności dostawcy) wymagają przeorientowania sposobu myślenia i działania w biznesie. Procesy dostosowawcze i zdolność przewidywania przyszłości, uznaje się za warunki przetrwania na dzisiejszym rynku (Kozielski, 2017).

Zdaniem Kozielskiego, ze względu na wspomniane uwarunkowania (zmienność otoczenia), obowiązują dzisiaj odmienne od tradycyjnych metody budowania biznesu. Priorytetowe przestały być: struktura, plan, skala czy funkcje w organizacji. Powstał nowy paradygmat, który autor nazywa architekturą czterolistnej koniczyny. Paradygmat ten opiera się na czterech zasadniczych elementach (Kozielski, 2017):

- możliwości biznesowe - firmy osiągają przewagę dzięki umiejętności identyfikacji możliwości biznesowych i podjęciu ryzyka ich wykorzystania (tzw. okno możliwości biznesowych). Te możliwości to obszary rynku zyskowne dziś i/lub w przyszłości. Jest to luka powstała w wyniku postępujących zmian rynkowych. Zidentyfikowane możliwości mogą prowadzić do mniej lub bardziej innowacyjnych przeobrażeń w produkcie, budowania nowych rynków, a nawet zmiany sposobów prowadzenia biznesu;

- koncept i model biznesowy - odnoszą sukces te organizacje, które mają zdolność budowy innowacyjnych konceptów i modeli biznesowych na podstawie zidentyfikowanych szans rynkowych. Kluczowy jest pomysł - identyfikacja potencjalnych klientów, określenie wartości, dla których klienci będą skłonni korzystać z oferty firmy i wybór skutecznych sposobów wyróżniania się na rynku;

- sprawność operacyjna - firmy z przewagą posiadają potencjał, by efektywnie realizować koncept i model biznesowy. Konieczna jest zatem umiejętność efektywnej realizacji przyjętego planu, jak również dynamicznej reakcji na zmianę rynkową. Fundamentem sprawnej organizacji jest współpraca, odpowiedzialność i zaangażowanie. To kluczowe umiejętności zwiększające szanse sukcesu firmy na rynku;

- kultura organizacyjna i silne przywództwo - szanse na rozwój w długim okresie daje eksperymentowanie w miejsce testowania, innowacyjność zamiast naśladownictwa. Żeby to realizować, potrzebny jest lider zdolny wykształcić godnych następców, budujący niezwykłą, trudną do kopiowania kulturę organizacyjną, klimat i podzielane przez członków organizacji wartości, w tym wartości etyczne.

Realizacja nowego paradygmatu na rynku wymaga wnikliwego spojrzenia na realia konkurencji i kluczowe źródła przewagi konkurencyjnej współczesnego przedsiębiorstwa. 
W literaturze przedmiotu istnieje zgodność co do podstawowego znaczenia przewagi konkurencyjnej dla funkcjonowania, przetrwania i rozwoju przedsiębiorstwa na rynku. Porter określił to przekonanie słowami: „Przewaga konkurencyjna jest duszą wyników firm na konkurencyjnych rynkach" (za: Stankiewicz, 2002: 103).

Wśród wielu definicji tego kluczowego zagadnienia warto przytoczyć ujęcie Stankiewicza, który przewagę konkurencyjną rozumie jako „zdolność do takiego wykorzystania potencjału konkurencyjności, jakie umożliwia na tyle efektywne generowanie atrakcyjnej oferty rynkowej i skutecznych instrumentów konkurowania, że zapewnia to powstanie wartości dodanej" (Stankiewicz, 2002: 172). Z kolei potencjał konkurencyjny definiowany jest jako „ogół zasobów materialnych i niematerialnych, niezbędnych do tego, aby przedsiębiorstwo mogło funkcjonować na rynkowej arenie konkurencyjności” (Stankiewicz, 2002: 93). Inaczej mówiąc „potencjałem konkurencyjności są te zasoby, którymi przedsiębiorstwo powinno dysponować, aby móc wykorzystać je do budowania, utrzymania i umacniania swojej konkurencyjności" (Stankiewicz, 2002: 103).

W literaturze przedmiotu podkreśla się, że to właśnie zasoby, a szczególnie kompetencje przedsiębiorstwa - i ich ciągły rozwój - są praktycznym warunkiem realizacji nowego paradygmatu na rynku (Kozielski, 2017).

Kompetencje są specyficzną i kluczową cechą przedsiębiorstwa i zatrudnionych w nim ludzi, w skład których wchodzi wiedza (w tym m.in. znajomość spraw związanych z uwarunkowaniami biznesu, know-how, technologie, metody i techniki konceptualizacji), doświadczenia ludzi i całego przedsiębiorstwa (w tym doświadczenia powstające na skutek rożnych projektów konkurencyjnych) i szeroko ujmowane zdolności (Stankiewicz, 2002). Te ostatnie, rozumiane jako umiejętność postępowania właściwego dla danej sytuacji (w tym zdolność do uczenia się), umiejętność przyjmowania odpowiednich do przedmiotu działania horyzontów myślenia, zdolności przywódcze kadry menedżerskiej, zdolność strategicznego myślenia, a ostatecznie zdolności osobowościowe (w tym kreatywność, wyobraźnia i intuicja) (Stankiewicz, 2002), są zdaniem wielu specjalistów kluczowe w osiąganiu sukcesu firmy na rynku.

Wspominany już wcześniej Kozielski podkreśla, że w dzisiejszych i przyszłych uwarunkowaniach rynkowych, ogromne znaczenie ma właśnie empatia rynkowa i zdolność budowania relacji, interdyscyplinarnego i spójnego spojrzenia na rynek, komunikacji, przede wszystkim umiejętność tworzenia treści i znajomości technologii, głównie algorytmów i procesów wykorzystywanych przez technologię. Podkreśla również, że umiejętność przystosowania się i zdolność przewidywania przyszłości jest wpisane i nieodzowne dla osiągania sukcesu na rynku (Kozielski, 2017).

Rozwój tych kompetencji daje podstawy do ukształtowania innego, równie ważnego zasobu (niematerialnego) - relacji wewnątrz organizacji i z interesariuszami zewnętrznymi (Klimas, Czakon, 2010).

Najbardziej efektywną formą relacji są relacje oparte na kulturze zaufania. Potencjał kultury zaufania w znacznym stopniu zależy od sposobu zarządzania przedsiębiorstwem i jego siecią powiązań (relacjami) z innymi podmiotami, m.in. od strategii, struktury organizacyjnej, modelu zarządzania zasobami ludzkimi, motywacji i kultury organizacyjnej (Aluchna, 2017; Kowalska, 2021). Na wszystkich tych poziomach czynnik zaufania odgrywa kluczową rolę, uwalnia potencjał i eliminuje bariery efektywnego działania. 
Punktem wyjścia w procesie budowania zaufania w relacjach sieciowych (dominujących w dzisiejszych realiach biznesowych) jest tworzenie zaufania wewnątrz danego przedsiębiorstwa. Budowanie zaufania w stosunku do pracowników, to podstawowy warunek utrwalania pozytywnych postaw $\mathrm{w}$ organizacji i na zewnątrz - w stosunku do pozostałych interesariuszy. Postawy te (kolejny ważny zasób niematerialny) są emanacją istniejącej w przedsiębiorstwie kultury organizacyjnej. Uwidaczniają się m.in. w nastawieniach do innowacji, do klientów, skłonnościach do ryzyka, wartościach, normach i zachowaniach (np. w zaangażowaniu i aktywności lub ich braku) (Stankiewicz, 2002).

Z racji rozbudowanych łańcuchów dostaw (nie tylko międzynarodowych korporacji), nastawienie na efektywne powiązania biznesowe oparte o czynnik zaufania (przede wszystkim w odniesieniu do kluczowych kontrahentów i klientów), ma fundamentalne znaczenie dla sprawności operacyjnej.

Podstawą zaufania opartego na identyfikacji (najwyższy poziomu zaufania) jest długotrwała, ścisła współpraca oparta na ciągłym dialogu, zorientowana na wspólne cele, normy i wartości (Kwiatkowski, 2000). W takich warunkach powiązania sieciowe umożliwiają osiąganie przewagi relacyjnej, sprzyjają powstawaniu innowacji, elastyczności i szybkości działania. Wysoki poziom zaufania podmiotów w układzie sieciowym eliminuje oportunizm, uruchamia twórcze myślenie, redukuje ryzyko działania usprawniając i intensyfikując tym samym wymianę wiedzy, wrażliwych informacji i doświadczeń.

Budowanie tego rodzaju relacji wymaga określonego podejścia mentalnego (dalekiego od kalkulacji „wygrana-przegrana”) i skutecznego wdrażania podejścia partnerskiego.

Podejście partnerskie, dużo bardziej efektywne od transakcyjnego, wymaga odejścia od prostego myślenia „siłowego" w stronę nowego paradygmatu „wygrana-wygrana" (win-win). W relacyjnym modelu (koncepcja Vested) partnerzy współpracują ze sobą na zasadzie wzajemnego zaufania, wsparcia i uczciwości. Istotnym elementem w takim podejściu jest proces budowania relacji, negocjowania nie tylko warunków umowy, ale również negocjowanie relacji między obiema stronami transakcji. Jest to proces daleki od tzw. mikrozarządzania partnerem biznesowym (Polak, 2016).

Jak podkreśla Kozielski, firmy, które chcą budować silną i odporną na zmiany markę, muszą być świadome znaczenia spójności i autentyczności w kluczowych ideach i efektach działania (Kozielski, 2017). Podstawą tej spójności jest właśnie budowanie relacji z interesariuszami firmy w optyce konsekwentnie kształtowanej reputacji (ważny przejaw omawianych relacji). Opinie otoczenia o przedsiębiorstwie i jego produktach przybierają postać nieformalną (np. uznania marki) i/lub formalną (np. nadania przedsiębiorstwu określonych certyfikatów jakości) (Stankiewicz, 2002). W praktyce mogą procentować zaufaniem, innowacyjnością i chęcią działania na rzecz wspólnie określonych celów.

Inną ważną kwestią jest fakt, iż marki mają do odegrania swoją rolę społeczną. Jak podkreśla się w literaturze przedmiotu, społeczna rola marki wiąże się z odpowiedzialnością (Buglewicz, 2017; Kozielski, 2017). Jest to dodatkowy obszar, który wymaga autentycznych relacji, empatii i umiejętności wielostronnego spojrzenia na relacje i zjawiska rynkowe. W praktyce ten obszar określa się społeczną odpowiedzialnością biznesu (CSR - Corporate Social Responsibility).

Pojęcie CSR wciąż ewoluuje. Można jednak zdefiniować je jako „świadome działanie podjęte $\mathrm{w}$ danej organizacji, inspirowane rezultatami dialogu społecznego 
i nakierowane na tworzenie społecznie istotnych wartości odpowiadającym oczekiwaniom interesariuszy" (Rojek-Nowosielska, 2017: 82).

Eksperci w zakresie CSR zgodnie podkreślają, że uwzględnianie w decyzjach szeroko rozumianych skutków oddziaływania firmy na otoczenie wynika z konieczności dostosowania się do realiów konkurencji na rynku. Coraz większe znaczenie ma bowiem minimalizowanie ryzyka reputacyjnego uzyskiwane poprzez kształtowanie takich rodzajów interakcji i powiązań w firmie i z otoczeniem, które redukują ryzyko błędów, nadużyć, oportunizmu, nielojalności i zbędnych kosztów transakcyjnych na rzecz wypracowywania wartości korzystnych dla wszystkich stron w biznesie. Wynikiem takiego podejścia jest często realizacja nieoczywistych projektów innowacyjnych, kreowanie okoliczności, które mogą sprzyjać tzw. serendipity, czyli czegoś, co jest wartościowe w biznesie i staje się przyczyną sukcesu (Kozielski, 2017).

Kozielski w tym kontekście zauważa, że firmy, które osiągają sukces „nie prowadzą już badania rynku, ale odkrywają insighty klienta. Nie produkują towarów, ale kreują obustronne wartości - dla klientów i organizacji. Nie budują struktur, funkcji, stanowisk, ale dbają o skuteczność, efektywność, wydajność. Nie przymuszają do pracy, a inspirują, wspierają w rozwoju" (Kozielski, 2017: 185).

\section{CHARAKTERYSTYKA DZIAŁANIA FIRMY ASTOR NA RYNKU}

Grupa ASTOR Sp. z o.o. spółka komandytowa, to firma, która w Polskiej Klasyfikacji Działalności (PKD) jest sklasyfikowana jako: Pozostała działalność usługowa w zakresie technologii informatycznych i komputerowych. To firma z polskim kapitałem marka technologiczna konsekwentnie budowana od ponad trzydziestu lat. Na polskim rynku jest jednym z liderów wśród dostawców rozwiązań z zakresu automatyzacji, robotyzacji i cyfryzacji procesów produkcyjnych.

ASTOR (ASTOR to skrót: Automatyka, Sterowanie, Transmisja, Oprogramowanie, Robotyka) powstała w 1987 roku. Jej liderem, a zarazem prezesem firmy jest Stefan Życzkowski. Firma wielokrotnie nagradzana i wyróżniana, w ostatnich latach to m.in. nagroda dla najlepszego dystrybutora produktów Emerson Industrial Automation \& Controls w Europie w roku 2018 - Distinguished multi year performance; nagroda Produkt Roku 2018 za kontroler PAC Systems CPE400 w kategorii sterowniki PLC i kontrolery PA (organizator konkursu: Control Engineering); nagroda firmy doradczej Frost \& Sullivan Polish Industrial Automation Customer Value Leadership Award, za osiągnięcie pozycji lidera jakości polskiej automatyki przemysłowej; ASTOR - Lider Polskiego Biznesu 2015 (organizator: Business Centre Club).

Firma ASTOR zatrudnia ponad 150 osób, ma w Polsce siedem lokalnych oddziałów handlowych. W branży, którą reprezentuje (i nie tylko), wyróżnia się specyficznym podejściem do zarządzania organizacją, które opiera się na wartościach humanistycznych (wartościach przysługujących człowiekowi i prawach z nimi związanych) i ich deklarowanym respektowaniem we wszystkich obszarach prowadzenia biznesu.

To model zarządzania oparty na wartościach. To przekonanie o podstawowej roli wartości w zrządzaniu firmą, świadomość ich wpływu na zachowania w organizacji, wyznaczanie kierunków działań i scalanie jej kluczowych elementów.

W praktyce to sposób zarządzania, który opiera się na założeniu, że zyski i rozwój firmy zależą od silnej bazy kapitału ludzkiego. Kapitał ludzki to oczywiście: 
wykształcenie, kwalifikacje zawodowe, moralność, rozwinięte talenty, zdrowie, a zatem integralny rozwój człowieka.

Przyjęcie takiej optyki znajduje odzwierciedlenie w jej motcie: „Gdzie technologia spotyka człowieka". W praktyce ma to oznaczać przyjęcie takiego kierunku działania, by w procesie automatyzacji i robotyzacji priorytetem był właśnie człowiek. Głównym punktem odniesienia w działaniu firmy w założeniu powinno być zatem autentyczne dbanie o rozwijanie kompetencji pracowników, klientów i partnerów biznesowych strategicznych interesariuszy firmy (ASTOR, 2019, 2020).

Dla wielu praktyków biznesu, zagadnienie wartości w procesie zarządzania może wydawać się „zbyt miękkie”. Dla kadry kierującej firmą ASTOR, to od lat rozwijana koncepcja prowadzenia biznesu (wyraźnie i konsekwentnie podkreślana i opisywana w dokumentach strategicznych firmy, wywiadach prasowych, konferencjach akademickich) opierająca się na założeniu, że w biznesie wartości stanowią fundament skutecznego działania i przetrwania organizacji na coraz bardziej wymagającym rynku. Kluczową kwestią jest tutaj szerokie spojrzenie na wartości w organizacji - uwzględnienie zarówno wartości ekonomicznych, jak i społecznych i etycznych, następnie zapewnienie akceptacji określonych wartości organizacyjnych wewnątrz i na zewnątrz organizacji. Wymaga to jednak autentycznego i praktycznego odniesienia do obranych wartości, szczególnie tych związanych z integralnym rozwojem człowieka.

Istniejąca współzależność pomiędzy wartościami społecznymi, etycznymi a ekonomicznymi daje podstawy do generowania planowanych zysków, ponieważ ukierunkowanie na wartości humanistyczne motywuje (rodzi naturalną, wewnętrzną zachętę) do przekraczania barier rozwoju, rodzi zaufanie i pozytywny rodzaj zobowiązania (oparty na woli, nie przymusie) do uczciwych praktyk i budowania wspólnych wartości w biznesie (ASTOR 2019, 2020; Mazurek, 2001; Szwajca, 2016).

W literaturze przedmiotu taki rodzaj myślenia i działania określa się mianem przedsiębiorczości intelektualnej. Lider charakteryzujący się tym rodzajem przedsiębiorczości charakteryzuje się pewnymi kompetencjami (połączeniem wiedzy i umiejętności), ma dużą kulturę umysłową, szczególną umiejętność gromadzenia wiedzy i jej przetwarzania, przewidywania pewnych zjawisk, jak również kształtowania rzeczywistości z uwzględnieniem najważniejszych zmian i wyzwań społecznych (Wyrzykowska, 2012).

Pojęcie przedsiębiorczości intelektualnej związane jest z koncepcją przywództwa transformacyjnego. Joanne Ciulla, założycielka interdyscyplinarnej szkoły przywództwa na świecie, zwraca uwagę, że zarówno przywódcy, jak i zwolennicy (uczestnicy systemu) mają obowiązek ciągłej poprawy systemów społecznych, opierając się na wspólnych wartościach. Przywódca i zwolennik jest nośnikiem określonych wartości (Wyrzykowska, 2012). Dzielenie wizji przez określoną liczbę osób zakłada społeczną relację opartą na współpracy, ukierunkowaną na zmianę przynoszącą określone korzyści.Istotna jest w tym kontekście umiejętność budowania „etycznego kapitału interesariuszy", który jest niematerialnym zasobem wzrastającym w miarę upływu czasu. Poziom tego kapitału jest wyznaczony przez gotowość interesariuszy do ciągłego wspierania działań firmy (Wyrzykowska, 2012).

Wspólne określenie wizji przez różnych interesariuszy ASTOR, współdzielenie tej wizji i budowanie kompetencji przedsiębiorstwa w oparciu o trwałe i dobre relacje z podmiotami otoczenia, stanowi wyznacznik działalności firmy. Widoczne jest w tym 
aspekcie szerokie spojrzenie na kwestie społeczno-gospodarcze i świadoma refleksja etyczna w procesie zarządzania firmą (tabela 1).

Tabela 1. Podstawowe założenia strategiczne ASTOR zawarte w dokumentach firmy

\begin{tabular}{|c|c|c|}
\hline $\begin{array}{c}\text { Kategorie } \\
\text { zarządzania }\end{array}$ & Treść & Uszczegółowienie \\
\hline Wizja ASTOR 2030 & $\begin{array}{l}\text { Odpowiedzialnie } \\
\text { i humanistycznie } \\
\text { prowadzimy do przemysłu } \\
\text { przyszłości. }\end{array}$ & $\begin{array}{l}\text { Odpowiedzialnie: wygrana win-win, rzetelność, } \\
\text { racjonalność biznesowa, partnerska współpraca, } \\
\text { doprowadzanie spraw do końca. } \\
\text { Humanistycznie: dbanie o dobro człowieka, } \\
\text { poszukiwanie sensu, dbałość o samorealizację, } \\
\text { ukierunkowanie na rozwój inżynierów - Inżynier } \\
\text { 4.0, zarządzanie w oparciu o współudział } \\
\text { i współwłasność. } \\
\text { Prowadzimy: ASTOR wiodąca polska firma, pomoc } \\
\text { w wygrywaniu, współpraca, prowadzenie szkoleń } \\
\text { i inspirowanie, wyznaczanie trendów. } \\
\text { Przemysł przyszłości: Przemysł 4.0, automatyzacja, } \\
\text { robotyzacja, cyfrowa transformacja fabryk. }\end{array}$ \\
\hline Misja ASTOR & $\begin{array}{l}\text { Chcemy razem, z pasją } \\
\text { i zaangażowaniem, } \\
\text { unowocześniać przemysł. } \\
\text { Wspieramy w rozwoju } \\
\text { ludzi, z którymi } \\
\text { współpracujemy. }\end{array}$ & $\begin{array}{l}\text { Interdyscyplinarny rozwój kompetencji i sprawności } \\
\text { operacyjnej. }\end{array}$ \\
\hline Wartości & $\begin{array}{l}\text { Wyznacznik, trzon } \\
\text { działalności. }\end{array}$ & $\begin{array}{l}\text { Harmonia życia rodzinnego i zawodowego. } \\
\text { Wzajemna pomoc i wsparcie: współpraca w zespole } \\
\text { i docenienie innych, podejście win-win, szacunek do } \\
\text { siebie nawzajem, do partnerów i klientów. } \\
\text { Wolność i odpowiedzialność: lojalność, } \\
\text { zaangażowanie, rzetelność. }\end{array}$ \\
\hline Cel nadrzędny & $\begin{array}{l}\text { Dynamiczny rozwój } \\
\text { firmy uzyskany poprzez } \\
\text { koncentrację na } \\
\text { powtarzalnej sprzedaży, } \\
\text { wzrost zwinności } \\
\text { organizacji, wspieranie } \\
\text { pracowników na każdym } \\
\text { etapie rozwoju oraz } \\
\text { usprawnianie narzędzi } \\
\text { IT wspierających obsługę } \\
\text { klientów. }\end{array}$ & $\begin{array}{l}\text { Sprzedaż traktowana jest jako rodzaj relacji } \\
\text { budowanej na zaangażowaniu i trosce o sukces } \\
\text { klienta. Sukces klienta i pozostałych interesariuszy } \\
\text { (wewnętrznych i zewnętrznych) przekłada się na } \\
\text { przewagę konkurencyjną firmy na rynku. }\end{array}$ \\
\hline $\begin{array}{l}\text { Sprawność } \\
\text { operacyjna }\end{array}$ & $\begin{array}{l}\text { Celem jest rozwój } \\
\text { zwinności (szybkości } \\
\text { i elastyczności) organizacji } \\
\text { poprzez optymalizację } \\
\text { procesów wewnętrznych } \\
\text { i usprawnienie narzędzi } \\
\text { IT bezpośrednio } \\
\text { wspierających sprzedaż. }\end{array}$ & $\begin{array}{l}\text { - codzienny bohater (wizja przekuta w działania } \\
\text { dnia codziennego); } \\
\text { - synergia strategii i sprawności operacyjnej } \\
\text { (elastyczność, innowacyjność, eksperymenty, } \\
\text { zmiany), } \\
\text { - projekty kontra hierarchia zarządzania (burzenie } \\
\text { silosów organizacyjnych), } \\
\text { - efektywność decyzyjna (dokąd mnie to } \\
\text { zaprowadzi?), } \\
\text { - pomiar, czyli widzieć, wiedzieć, rozumieć } \\
\text { (efektywność działania, efekty działań rynkowych). }\end{array}$ \\
\hline
\end{tabular}




\begin{tabular}{|c|c|c|}
\hline $\begin{array}{l}\text { Kultura } \\
\text { organizacyjna }\end{array}$ & $\begin{array}{l}\text { Celem jest wspieranie } \\
\text { pracowników na } \\
\text { każdym etapie rozwoju } \\
\text { zawodowego oraz } \\
\text { zwiększenie ich motywacji. }\end{array}$ & $\begin{array}{l}\text { - zapewnienie przestrzeni do dzielenia się wiedzą } \\
\text { i do eksperymentowania, } \\
\text { - nauka celebrowania sukcesów, } \\
\text { - dostrzeganie i docenianie mocnych stron, } \\
\text { - wypracowanie nawyku dzielenia się wiedzą. }\end{array}$ \\
\hline Lider & $\begin{array}{l}\text { Przewodniczy inspiruje, } \\
\text { wychowuje liderów. }\end{array}$ & $\begin{array}{l}\text { - patrzy całościowo, dostrzega kompletny obraz, } \\
\text { - odnajduje i pokonuje bariery w rozwoju firmy, } \\
\text { - doskonali działanie firmy, } \\
\text { - dąży do rozwoju firmy, } \\
\text { - patrzy strategicznie, } \\
\text { - w decydującym stopniu wpływa na charakter } \\
\text { kultury organizacyjnej (normy, zasady, wartości). }\end{array}$ \\
\hline Organizacja & Fabryka liderów. & $\begin{array}{l}\text { Kultura organizacyjna - niewidzialna siła } \\
\text { i prawdziwa moc. } \\
\text { Kultura sukcesu - ma własny, wyjątkowy charakter, } \\
\text { powinna być prawdziwa, opierać się na normach } \\
\text { i zachowaniach, które są jej zobrazowaniem. } \\
\text { Integruje koncept i model ze strategią i sprawnością, } \\
\text { uczy i wychowuje liderów. } \\
\text { Kultura organizacji uczącej się - uczenie się rynku, } \\
\text { zdolność szybkiego rozpoznawania, przewidywania } \\
\text { zmian i adaptacji do nich. Wyciąganie wniosków, } \\
\text { doskonalenie i ciągła zmiana. }\end{array}$ \\
\hline
\end{tabular}

Źródło: opracowanie własne na podstawie (ASTOR, 2019, 2020)

Klientami firmy ASTOR są: integratorzy automatyki, producenci maszyn i urządzeń, firmy produkcyjne, uczelnie i szkoły, jak również projektanci (ASTOR, 2019, 2020).

Firma ASTOR jest liderem w zakresie propagowania idei Przemysłu 4.0 (tzw. czwartej rewolucji przemysłowej) w Polsce. Poprzez liczne warsztaty wspiera klientów w budowaniu map drogowych do Przemysłu 4.0 - w tym celu powstała Akademia Przemysłu 4.0. Stanowi ona odpowiedź na realne potrzeby menedżerów i inżynierów, którzy w dobie transformacji cyfrowej poszukują wiedzy i kompetencji na styku wielu obszarów. Firma ASTOR, w kooperacji z partnerami, stworzyła sfery nauki, kompleksowy program rozwoju kompetencji pracowników w obszarze Przemysłu 4.0.

Firma, kładąc ogromny nacisk na realizację projektu Inżynier 4.0, przygotowała program kompetencji Inżynier 4.0, któremu towarzyszy rozbudowana oferta szkoleń i usług doradczych.

Mając na uwadze fakt, iż temat innowacyjności i technologii jest dla przeciętnego Polaka nadal obszarem trudnym i zarezerwowanym dla wąskiej grupy społecznej, zarząd ASTOR zdecydował się zwalczać ten problem poprzez otwarcie ASTOR Innovation Room (AIR) - interaktywnej wystawy robotyki i technologii IT w krakowskiej siedzibie firmy.

Jest to unikalne na skalę europejską miejsce, gdzie z technologią może spotkać się tak profesjonalista, jak i przechodzień.

W praktyce to interaktywna wystawa robotyki i technologii IT, gdzie prezentowane są procesy produkcyjne spawania, paletyzacji i pakowania, wykonywane przez roboty. To miejsce, w którym działają nowoczesne systemy produkcyjne oparte na robotach Kawasaki i Epson, nadzorowane przez sterowniki GE Intelligent Platforms oraz oprogramowanie SCADA i MES firmy Wonderware. 
To również miejsce, gdzie firmy produkcyjne mogą nie tylko zaobserwować zautomatyzowaną produkcję, ale również bez dodatkowych kosztów wykonać testy robotyzacji procesów zachodzących w ich zakładach (ASTOR, 2019, 2020).

W ASTOR Innovation Room Akademia ASTOR prowadzone są również szkolenia z zakresu robotów przemysłowych.

Projekt ten to również, poza skuteczną formą proporcji marki na rynku, próba dotarcia do szkół, przedszkoli z informacją, że technologia może wspierać i ułatwiać codzienne życie (firma zachęca na swojej stronie internetowej i w przekazach medialnych, do umówienia bezpłatnej wizyty w AIR). Można powiedzieć, że jest to miejsce do zaszczepiania pasji do innowacji wśród najmłodszych i młodzieży (ASTOR, 2019, 2020).

Odpowiedzialność firmy (szerszy i etyczny kontekst postrzegania rzeczywistości i biznesu) to liczne działania charytatywne realizowane przez ASTOR. ASTOR od lat współdziała z organizacjami non-profit, wspiera akcje charytatywne; pomoc kieruje zwłaszcza do dzieci. Corocznie, 2\% zysku wypracowanego w poprzednim roku firma przeznacza na cele charytatywne. Jednym z ważniejszych projektów charytatywnych firmy jest znana akcja: Szlachetna Paczka.

Z kolei w zakresie edukacji przyszłej kadry inżynierskiej firma ASTOR współpracuje z największymi w Polsce technicznymi uczelniami wyższymi, tworząc pomost między środowiskiem naukowym, studentami oraz biznesem. Co istotne, ASTOR wspiera uczelnie i szkoły techniczne w tworzeniu stanowisk laboratoryjnych. Dodatkowo firma brała udział w programach praktyk studenckich (Cień Menadżera) i corocznie przyjmuje studentów na praktyki w swoich biurach w całej Polsce (ASTOR, 2019, 2020).

Odpowiedzialne podejście firmy ASTOR do biznesu to również polityka środowiskowa, realizowana poprzez minimalizowanie negatywnego wpływu na otoczenie w ramach zrównoważonego zarządzania biurem, flotą samochodową oraz ograniczania i zagospodarowania wytworzonych odpadów (ASTOR, 2019, 2020).

Środowiskowe działania ASTOR to przede wszystkim: ograniczenie obiegu papierowej dokumentacji poprzez zastąpienie jej wersjami elektronicznymi; stała współpraca z firmami recyclingowymi odbierającymi od firmy makulaturę, opakowania styropianowe, i elektrośmieci; pakowanie towaru w opakowania wyłącznie kartonowe, które mogą być ponownie wykorzystane bądź bardzo łatwo zutylizowane lub przetworzone; wspieranie akcji lokalnych, jak inicjatywę zbierania plastikowych nakrętek, zużytych tonerów (dochód z ich sprzedaży firma przekazuje na leczenie i rehabilitację osób niepełnosprawnych); wdrażanie rozwiązań ułatwiających pracę zdalną, np. aplikacja Mobilny Pracownik - rozpoczęte kilka lat przed pandemią COVID-19 (ASTOR, 2016, 2017, 2018, 2019, 2020).

Dodatkowo, firma realizuje omawianą politykę poprzez wybór partnerów do współpracy w oparciu o kryterium środowiskowe (firmy przyjazne środowisku oraz takie, które stosują politykę środowiskową), zwiększanie świadomości ekologicznej pracowników firmy ASTOR, jej klientów i dostawców poprzez komunikację i dedykowane szkolenia w tym zakresie. To również ważne decyzje inwestycyjne, np. związane z flotą samochodową, która w 80\% składa się z samochodów spełniających najwyższe w UE normy emisji spalin, co ma odzwierciedlenie zarówno w ekonomice podróżowania, jak i ograniczeniu negatywnego wpływu na środowisko (ASTOR, 2016, 2017, 2018, 2019, 2020). 
Biorąc pod uwagę fakt, że gospodarka o obiegu zamkniętym (GOZ, circular economy) to w praktyce wszystkie działania, które prowadzą do redukcji, ponownego wykorzystania i przetworzenia materiałów w procesach produkcji, dystrybucji i konsumpcji (Geisendorf, Pietrulla, 2018; Horbach, Rammer, 2019; Korsunova, Horn, Vainio, 2021), można wy ciągnąć wniosek, że działania firmy ASTOR mocno wpisują się w założenia GOZ.

Jak już wcześniej wspomniano, polityka odpowiedzialności omawianej firmy bazuje na wartościach, kulturze organizacyjnej i ukształtowanych postawach pracowników. Jest konsekwencją przyjętej optyki myślenia i działania w biznesie. Wdrażana polityka odpowiedzialności buduje pozytywny wizerunek firmy na rynku, widoczny zarówno w opiniach ankietowanych przez firmę ASTOR interesariuszy (np.: „Sprzedawca ASTOR to inżynier-doradca, a nie akwizytor”; „Nie zostawiają z problemem”; „Zawsze otwarci i szczerzy. Można im zaufać"), jak i w decyzjach rynkowych klientów i partnerów firmy (ASTOR, 2019, 2020).

Można przypuszczać, że polityka odpowiedzialności jest również początkiem tzw. innowacji otwartych, w których klienci i partnerzy biznesowi, w atmosferze zaufania i otwartości, naprowadzają (mniej lub bardziej świadomie) pracowników ASTOR na rozwiązania, które przekładają się na sukces firmy. Relacje uczciwe, w podejściu win-win, ułatwiają identyfikacje istniejących możliwości biznesowych.

\section{ZAKOŃCZENIE}

Analiza podstawowych założeń strategicznych firmy ASTOR (w oparciu o udostępnione materiały źródłowe firmy) i pogłębiony wywiad przeprowadzony z Renatą Poredą, manager ds. komunikacji marketingowej i PR firmy ASTOR, pozwala wyciągnąć wniosek, że to, co stanowi źródło sukcesu firmy na rynku, to unikalna kultura organizacyjna i konsekwentnie rozwijane kompetencje firmy. To autentyczne bazowanie na wartościach, takich jak podejście win-win, wartości rodzinne, wzajemna pomoc, odpowiedzialność, współpraca w zespole i docenianie różnic, szacunek dla siebie nawzajem, klientów, dostawców, harmonia życia zawodowego i rodzinnego. To również ukierunkowanie pracy i współpracy na budowanie silnej i odpowiedzialnej marki. Marki, która ma stanowić (i w praktyce tak jest oceniana w badaniach ankietowych przez klientów i kooperantów) realną obietnicę sukcesu podmiotów wchodzących w relacje z firmą ASTOR.

Odpowiedzialny, oparty na powszechnie akceptowanych wartościach, sposób myślenia o biznesie, zapoczątkowany i rozwijany przez lidera, a następnie rozwijany przez zarząd i pracowników ASTOR, można uznać za przejaw przedsiębiorczości intelektualnej.

To pewien rodzaj wykorzystania możliwości rynkowych, ale również kształtowania otoczenia (generowania szans) poprzez odpowiedzialne podejście relacyjne do swoich interesariuszy, jak również do kwestii społecznych i środowiskowych.

To przykład świadomego wyboru na rzecz etyki aspiracji (kreatywne budowanie świadomości etycznej, etyczne przywództwo), w odróżnieniu od bazowania jedynie na tzw. etyce obowiązku (unikania problemów).

Ukierunkowanie na etykę inspiracji lidera ASTOR i zarządzających firmą, w praktyce przyjęcie optyki CSR w biznesie, wydaje się być podstawą sprawności operacyjnej przedsiębiorstwa, ponieważ stwarza warunki do rozwoju współpracy, zaufania, 
otwartości i elastyczności działania. CSR bowiem otwiera drogę do różnego rodzaju pomysłów, innowacji zarówno o charakterze produktowym, jak i procesowym.

Odpowiedzialne podejście w firmie ASTOR, oparte o kluczowe dla interesariuszy wartości, tworzy specyficzny klimat; rodzi chęć zaangażowania i działania na rzecz efektywnej współpracy.

Wiele lat temu, w omawianym kontekście, ekspert ds. zarządzania, Peter Drucker, stwierdził, że najwydajniejsza jest praca ochotnika, a najmniej wydajna jest praca niewolnika (Kwiatkowski, 2000). Tą myśl można dostrzec w podstawowych założeniach i praktykach działania omawianej firmy.

Przywołany w artykule projekt ASTOR Innovation Room (AIR), przynoszący codzienne korzyści firmie i jej interesariuszom, to właśnie efekt pasji i zaangażowania pracowników i kontrahentów, którzy pracując zespołowo wzajemnie się inspirują i edukują (ASTOR, 2019, 2020). Jak podkreślają zarządzający firmą, „biznesu nie da się prowadzić w pojedynkę. Wzajemne oddziaływanie i współpraca różnych grup to klucz do rozwoju, wzrostu, a tym samym szukania nowych możliwości biznesowych" (ASTOR, 2019, 2020).

Należy również podkreślić, że odpowiedzialne podejście nastawione na kształtowanie trwałych i etycznych relacji z interesariuszami firmy, to w praktyce najtrudniejsze (a często niemożliwe) do skopiowania źródła sukcesu firmy na rynku. Takie relacje składają się na unikalną kulturę organizacyjną firmy, elastyczność (szybkość reakcji na zmieniające się otoczenie) i łatwość mobilizowania odbiorców do budowania wspólnych wartości.

Odpowiedzialność firmy (szerszy i etyczny kontekst postrzegania rzeczywistości i biznesu) to wybór relacji win-win w relacji B2B (między przedsiębiorstwami), nastawienie na wsparcie i rozwój klientów, odpowiedzialny dobór dostawców i partnerów, a przede wszystkim dobór pracowników ASTOR o ściśle wymaganych kwalifikacjach i umiejętnościach związanych z działalnością i wrażliwością na rynek (np. wśród pracowników ASTOR jest wielu pasjonatów przyrody i propagatorów ekologicznego sposobu życia, którym bliska jest dbałość o środowisko).

Przekłada się to na tzw. empatię rynkową i zdolność wyczucia rynku, które pozwalają działać firmie zgodnie z oczekiwaniami jej najważniejszych interesariuszy.

Zastosowanie partnerskiej koncepcji współpracy przez firmę ASTOR, opartej na zaufaniu, transparentności i wymianie informacji, ostatecznie podnosi konkurencyjność całego łańcucha dostaw, który w dużym stopniu zależy od charakteru relacji, jakie łączą podmioty wchodzące w jego skład.

Wydaje się, że firma ASTOR spełnia kryteria sukcesu określane przez specjalistów - technologia, profesjonalizm, analityka, empatia rynkowa, spójność i autentyczność.

Na zakończenie należy pokreślić, że spójność i autentyczność marki w jej odpowiedzialnej społecznie roli, wyklucza stosowanie podwójnych standardów odpowiedzialnego biznesu, charakterystycznych szczególnie dla praktyk międzynarodowych korporacji, ale również wielu mniejszych przedsiębiorstw funkcjonujących na krajowym i zagranicznym rynku (Kowalska, 2012).

Ciągłe nastawienie na rozwój, wieloletnia spójność i konsekwencja w wdrażaniu zasad i idei odpowiedzialności w biznesie (obrany kierunek rozwoju biznesu i jednoczesny brak doniesień medialnych o negatywnych praktykach firmy na rynku) wydają się być ważnym wyróżnikiem i źródłem innowacyjności firmy ASTOR. 
Taki model rozwoju firmy, ukierunkowany na tworzenie wartości ekonomicznej, jak i społecznej, ma również kluczowe znaczenie dla reputacji firmy ASTOR na rynku.

\section{Literatura \\ References}

Aluchna, M. (2017). Społeczna odpowiedzialność biznesu a innowacyjność. W: P. Płoszajski (red.), Czy społeczna odpowiedzialność firmy wspomaga jej innowacyjność? Warszawa: Oficyna Wydawnicza SGH.

ASTOR. (2016-2020). Materiały wewnętrzne firmy.

Buglewicz, K. (2017). Społeczna odpowiedzialność biznesu. Nowa wartość konkurencyjna. Warszawa: Polskie Wydawnictwo Ekonomiczne.

Geisendorf, S., Pietrulla, F. (2018). The circular economy and circular economic concepts - a literature analysis and redefinition. Thunderbird International Business Review, 60(5), 771-782. doi: $10.1002 /$ tie. 21924

Horbach, J., Rammer, Ch. (2019). Circular economy innovations, growth and employment at the firm level. Empirical evidence from Germany. Journal of Industrial Ecology, 24(3), 1-11. doi: $10.1111 /$ jiec.12977

Klimas, P., Czakon, W. (2010). Relacje z interesariuszami źródłem przewagi konkurencyjnej przedsiębiorstw. Prace Naukowe Uniwersytetu Ekonomicznego we Wrocławiu, 116, 160-168.

Korsunova, A., Horn, S., Vainio, A. (2021). Understanding circular economy in everyday life. Perceptions of young adults in the finnish context. Sustainable Production and Consumption, 26, 759-769. doi: 10.1016/j.spc.2020.12.038

Kowalska, K. (2012). Rozwój polskich sieci detalicznych jako sposób ograniczania siły rynkowej międzynarodowych korporacji handlowych. Warszawa: Wydawnictwo Difin.

Kowalska, K. (2021). Biznes społecznie odpowiedzialny jako forma przedsiębiorczości intelektualnej. W: E. Radomska, J. Pach, P. Nowak (red.), Ekonomia i przedsiębiorczość społeczna, Warszawa: Wydawnictwo CeDeWu.

Kozielski, R. (2017). Biznes nowych możliwości. Czterolistna koniczyna - nowy paradygmat biznesu. Piaseczno: Wydawnictwo Nieoczywiste.

Kwiatkowski, S. (2000). Przedsiębiorczość intelektualna. Warszawa: Wydawnictwo Naukowe PWN.

Mazurek, F.J. (2001). Godność osoby ludzkiej podstawq praw człowieka. Lublin: Redakcja Wydawnictw KUL.

Polak, P. (2016). Znaczenie relacji partnerskich w zarządzaniu łańcuchem dostaw - zastosowanie koncepcji Vested jako źródło przewagi konkurencyjnej we współczesnym biznesie. W: K. Rutkowski (red.), Zarządzanie łańcuchem dostaw w XXI wieku. W poszukiwaniu nowych źródeł przewagi konkurencyjnej. Warszawa: Oficyna Wydawnicza SGH.

Rojek-Nowosielska, M. (2017). Społeczna odpowiedzialność przedsiębiorstw. Model-diagnoza-ocena. Wrocław: Wydawnictwo Uniwersytetu Ekonomicznego.

Stankiewicz, M.J. (2002). Konkurencyjność przedsiębiorstwa. Budowanie konkurencyjności przedsiębiorstwa w warunkach globalizacji. Toruń: Dom Organizatora.

Szwajca, D. (2016). Zarządzanie reputacją przedsiębiorstwa. Warszawa: Wydawnictwo CeDeWu.

Wyrzykowska, B. (2012). Przedsiębiorczość intelektualna jako kompetencja współczesnego menedżera. Zeszyty Naukowe SGGW w Warszawie. Ekonomika i Organizacja Gospodarki Żywnościowej, 100, 25-36.

Katarzyna Kowalska, doktor, adiunkt, Uniwersytet Pedagogiczny w Krakowie, Instytut Prawa i Ekonomii, Katedra Ekonomii i Polityki Gospodarczej. Zainteresowania naukowe koncentrują się wokół etyki biznesu, społecznej odpowiedzialności biznesu (CSR), konkurencji przedsiębiorstw, internacjonalizacji przedsiębiorstw, strategii marketingowych, gospodarki cyrkularnej i modeli biznesowych umożliwiających jej wdrażanie. Autorka odbyła staż i prowadziła szkolenia dla Izby Rzemieślniczej Małej i Średniej Przedsiębiorczości w Katowicach. Jest współautorką wielowariantowej oceny lokalizacji wielkopowierzchniowych obiektów handlowych na wybranych rynkach lokalnych w Polsce, a także autorem monografii i artykułów naukowych z zakresu ekonomii. 
Katarzyna Kowalska, PhD, assistant professor, Pedagogical University of Krakow, Institute of Law and Economics, Department of Economics and Economic Policy. Her research focuses on business ethics, Corporate Social Responsibility (CSR), corporate competition, internationalisation of enterprises, marketing strategies, circular economy and business models for its implementation. She completed an internship and conducted training for the Craft Chamber of Small and Medium Enterpreneurship in Katowice. She is a co-author of multi-variant location assessment of large-format retail facilities on selected local markets in Poland. Author of monographs and scientific articles in the field of economics.

ORCID: https://orcid.org/0000-0003-2816-1802

\section{Adres/address:}

Uniwersytet Pedagogiczny w Krakowie

Instytut Prawa i Ekonomiiw

Katedra Ekonomii i Polityki Gospodarczej

ul. Podchorążych 2

30-084 Kraków, Polska

e-mail: katarzyna.kowalska@up.krakow.pl 